УДК 339.944:004

DOI: https://doi.org/10.37320/2415-3583/7.15

Рощина Н.В.

кандидат економічних наук, доцент,

Національний технічний університет Украӥни

«Київський політехнічний інститут імені Ігоря Сікорського»

Борданова Л.С.

кандидат економічних наук,

Національний технічний університет України

«Київький політехнічний інститут імені Ігоря Сікорського»

\title{
РЕТРОСПЕКТИВНИЙ АНАЛІЗ ІНФОРМАЦІЙНО-ТЕХНОЛОГІЧНОГО РИНКУ УКРАЇНИ
}

У сучасному світі розвиток інформаційно-технологічного ринку набирає усе більших обертів. IT-сфера динамічно інтегрується в усі галузі світової економіки, безпосередньо впливаючи на загальне зростання економічних та соиіальних показників підприємств та організаџій. Розуміння важливості інформаційних технологій для формування стійких конкурентних позицій організацій, розвитку всіх напрямів діяльності, підвищення якості товарів та послуг тошо приводить до стійкого попиту на иі технології. У такий спосіб відбувається взаємний вплив ІТ-сфери та інших економічних галузей у зовнішньому середовищі на транснаціональному масштабі. Для України IT-сфера має особливе значення, адже на фоні загальної економічної та політичної кризи вона здатна згладити иі явища за допомогою стрімкого розвитку, а також забезпечення функиіонування багатьох суміжних галузей [1]. У статті проаналізовано склад інформаційно-технологічного ринку Украӥни, а саме розглянуто динаміку розвитку, склад та розподіл спеціалістів за містами, компаніями; проаналізовано напрями діяльності основних гравиів на ринку. Все ие дало основу для підбиття підсумків та складення прогнозів щодо ринку інформаційних технологій. Висновки не стали несподіваними, оскільки IT-сфера стрімко розвивається по всьому світі.

Ключові слова: інформаційно-технологічний ринок, IT-сфера, аналіз, динаміка.

Постановка проблеми. Сектор інформаційних технологій з роками дуже стрімко посилює ефект на глобальну економіку. Створюючи дохід i наймаючи працівників за відносно високою середньою заробітною платою, ІТ-сектор також допомагає іншим секторам підвищити продуктивність та темп розвитку, не говорячи вже про те, що інформаційні технології можуть бути рушійною силою на ринках і створити трансформаційну цінність бізнесу в широкому діапазоні галузей та ринків.

За таких умов ринок IT з роками буде тільки підвищувати обсяг грошей i, як наслідок, вплив на економічні системи держав більшої частини світу. У зв'язку з цим за динамікою розвитку цієї галузі в країні з високою вірогідністю можна спрогнозувати розвиток загалом.

Аналіз останніх досліджень і публікацій. Проблеми сектору інформаційних технологій, створення та функціонування мережевих організацій 3 використанням інформаційних технологій аналізуються в роботах В. Вютріха, П. Зібера, Т. Іванової, М. Кастельса, Б. Мільнера, І. Пономарьова, В. Сердюка, В. Тарасова. Змістовні, функціональні та структурні характеристики віртуальних організацій були предметом досліджень Д. Берна, К. Бойченко, К. Бутурлакіної, С. Голдмана, У. Давидова, М. Дементьєвої, О. Катаєва, О. Клочко, У. Малоуна, А. Маслової, В. Мейтус, Р. Найджела, Т. Подчасової, М. Уорнера та інших авторів.
Мета статті полягає в аналізі складу інформаційно-технологічного ринку України.

Виклад основного матеріалу. Ринок IT-послуг в Україні постійно зростає. Згідно 3 недавнім аналізом PwC [2] ринок збільшився на $150 \%$ за 2011-2015 роки, у 2019 році він склав близько $30 \%$, а до 2020 року його капіталізація досягне 5,7 млрд. доларів (рис. 1).

Незважаючи на зростаючу кількість стартапів та компаній-виробників, аутсорсинг залишається провідним сегментом українського IT-сектору. У I півріччі 2017 року обсяги експорту IT зросли на $18,3 \%$ (до 1,256 млрд. дол. США) порівняно 3 аналогічним періодом 2016 року. Експорт комп'ютерних послуг у 2019 році приніс в економіку країни близько $\$ 3,5$ млрд. В середньому IT-індустрія зростала на 20-25\% щорічно завдяки сприятливій кон'юнктурі міжнародного ринку й попиту на розробки українських фахівців. За результатами перших шести місяців 2019 року експорт комп'ютерних послуг склав близько $\$ 1,6$ млрд, що на $31 \%$ більше, ніж в аналогічний період 2018 року. Це робить інформаційну технологію третьою за величиною галуззю в Україні за обсягами експорту, що становить більше 3\% ВВП (15\% до 2020 року).

За даними низки джерел експорт становить від 75\% до 90\% загальних IT-послуг, що надаються місцевими компаніями, порівняно з 8\%, що виділяються на внутрішні проєкти. Саме розроблення 


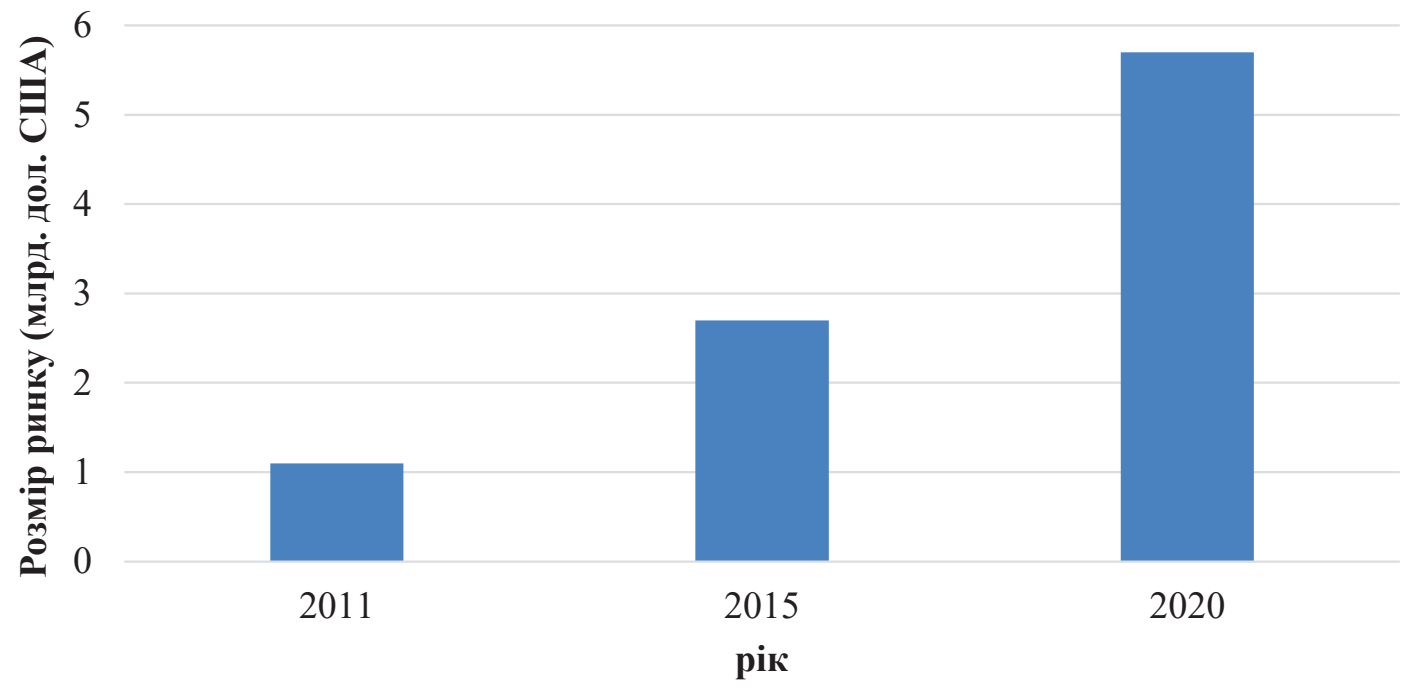

Рисунок 1 - Динаміка розміру українського IT-ринку

Джерело: [4]

програмного забезпечення становить понад 70\% обсягу аутсорсингу в Україні.

Зростає також кількість фахівців, які працюють в IT-галузі. За деякими оцінками на середину 2018 року в індустрії налічувалося близько 130 тисяч фахівців, за останнє півріччя їх кількість зросла майже на 20 тисяч осіб, а зараз, за даними асоціації "IT Ukraine”, на ринку налічується понад 160 тисяч фахівців, що на 22\% більше, ніж роком раніше. При цьому індустрія досі відчуває нестачу кваліфікованих інженерів.

Постійно зростає також кількість компаній, що розробляють програмне забезпечення в Україні: 3 940 у 2009 році до 1050 у 2011 році. Нині, згідно 3 різними даними, їхня кількість коливається від 1391 до 1650.
Реальна кількість IT-компаній в Україні, можливо, буде значно вищою, якщо брати до уваги невеликі веб-студії, де менше 10 розробників та агентств мають одного великого клієнта. Такі компанії часто не мають ресурсів для просування себе або надто молоді, щоби бути зареєстрованими в будь-яких списках або каталогах.

Останні дослідження компанії “StackOverflow” [3] показали, що в Україні близько 166 тисяч розробників програмного забезпечення, а це приблизно $35 \%$ від загальної кількості інженерів у Центральній та Східній Європі. Понад 40\% українських програмістів живуть у Києві. Інші міста також не відстають, слід назвати Харків, Львів, Дніпро та Одесу (рис. 2).

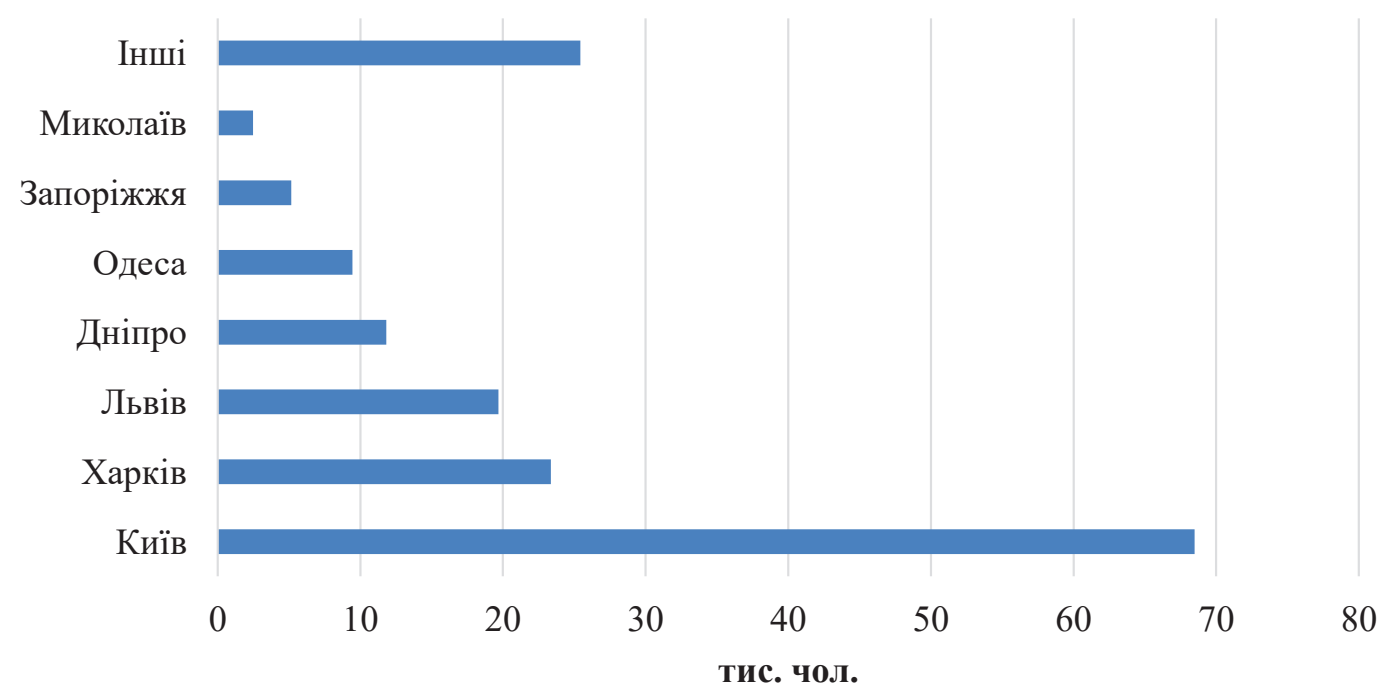

Рисунок 2 - Розміщення розробників у найбільших містах України 
Більшість джерел свідчить про те, що приблизно 60\% українських розробників програмного забезпечення нині працюють на аутсорсинг. Саме тому не дивно, що більшість компаній, що експортують IT-послуги, розташована в містах 3 найбільшою кількістю розробників. Наприклад, у Києві налічується понад 40\% усіх компаній, що займаються розробленням програмного забезпечення в Україні (рис. 3).

Більшість місцевих компаній $з$ розроблення програмного забезпечення складають середні за розміром підприємства: 41\% продавців, перерахованих у звіті "Ukraine Digital News" [5], мають 20-99 співробітників, а підприємства зі 100-299 співробітниками становлять ще $18 \%$ (рис. 4).

Слід зазначити, що багато невеликих компаній $з$ розроблення програмного забезпечення (<20 працівників) в Україні - це веб-студії або малі групи розробників, які працюють 3 одним клієнтом.

Проте доходи деяких найбільших компаній розробників програмного забезпечення в Україні також можуть залежати від одного великого клієнта. Тоді більшість розробників наймається на роботу над основним проєктом, і якщо клієнт покидає їх, то компанія 3 розроблення повинна реструктуруватись, знайти нового клієнта або звільнити більшість своїх співробітників.

Багато великих компаній з розроблення програмного забезпечення, що працюють в Україні, мають штаб-квартиру в інших країнах, включаючи США, Ізраїль, Данію та Швейцарію. Більш того, деякі українські компанії розширюються за межами України, відкриваючи офіси в Польщі, Болгарії, Румунії, Білорусі та Іспанії.

Згідно 3 "Ukrainian Hi-Tech Initiative" [6] Сполучені Штати залишаються ключовим цільовим

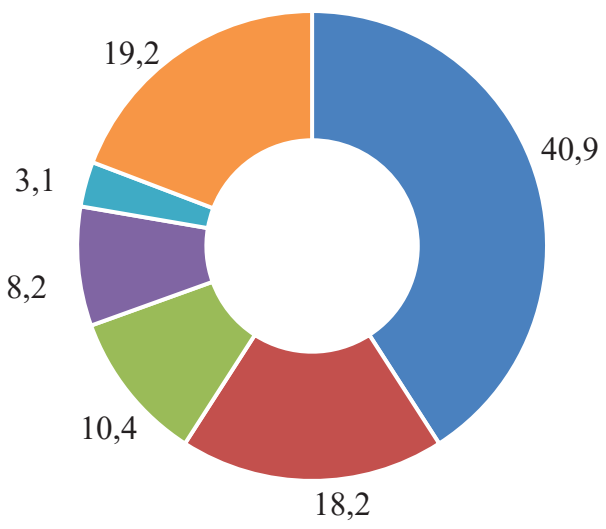

- Київ - Харків - Львів - Дніпро - Одеса " Інші

Рисунок 3 - Найпопулярніші міста серед українських компаній - розробників ПЗ

Джерело: [4] ринком для більшості українських компаній, що займаються розробленням програмного забезпечення, і займають близько 80\% експортованих IT-послуг. Країни СC, особливо Північний блок, та Ізраїль також $\epsilon$ серед популярних країн експорту, що не дивно з огляду на географічну близькість та брак місцевих ресурсів у цих регіонах (рис. 5).

Найпопулярнішими діловими доменами серед компаній, що займаються розробленням програмного забезпечення в Україні, $\epsilon$ електронна комерція, підприємництво та фінанси. Майже $50 \%$ постачальників, перерахованих на "Clutch. co", належать до однієї з цих трьох галузей. Інші популярні бізнес-галузі включають освіту, охорону здоров'я, подорожі (техніку) та телекомунікації (рис. 6).

Найбільш популярними технологіями інтернет-розроблення серед українських компаній $€$ PHP, Python/Django, NET та Java. CMS, включаючи Drupal та Wordpress, є менш популярними. (рис. 7)

Неможливо оцінити частку ринку мобільного розроблення в Україні, адже більшість компаній, що розробляють програмне забезпечення, пропонує послуги з розроблення веб-сайтів та мобільних додатків.

Щодо основної уваги мобільного розвитку, то більшість українських провайдерів має тенденцію до зосередження на власних розробках iOS та Android. Гібридні та крос-платформенні рішення втрачають популярність серед українських компаній.

Основною цільовою аудиторією компаній мобільного розвитку в Україні $\epsilon$ малий бізнес та стартапи (51\% компаній називає ці сегменти ринку основними).

Більше $60 \%$ компаній, що спеціалізуються на розробленні мобільних додатків, пропонують

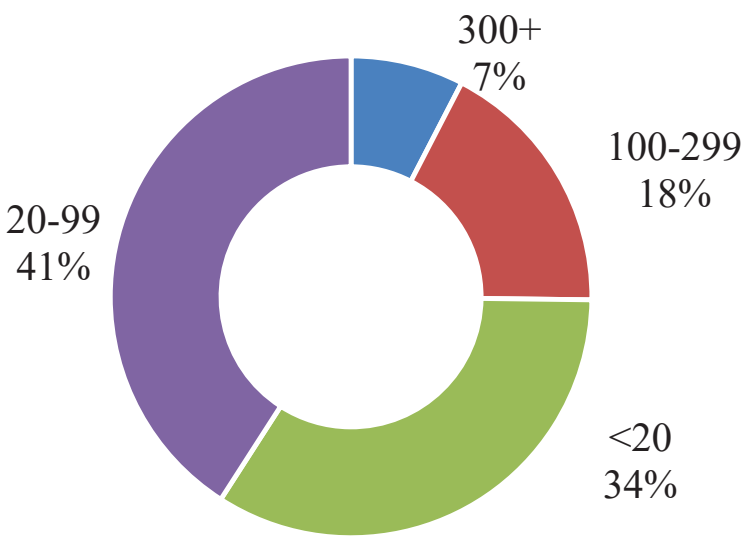

Рисунок 4 - Компанії - розробники програмного забезпечення за кількістю співробітників

Джерело: [5] 


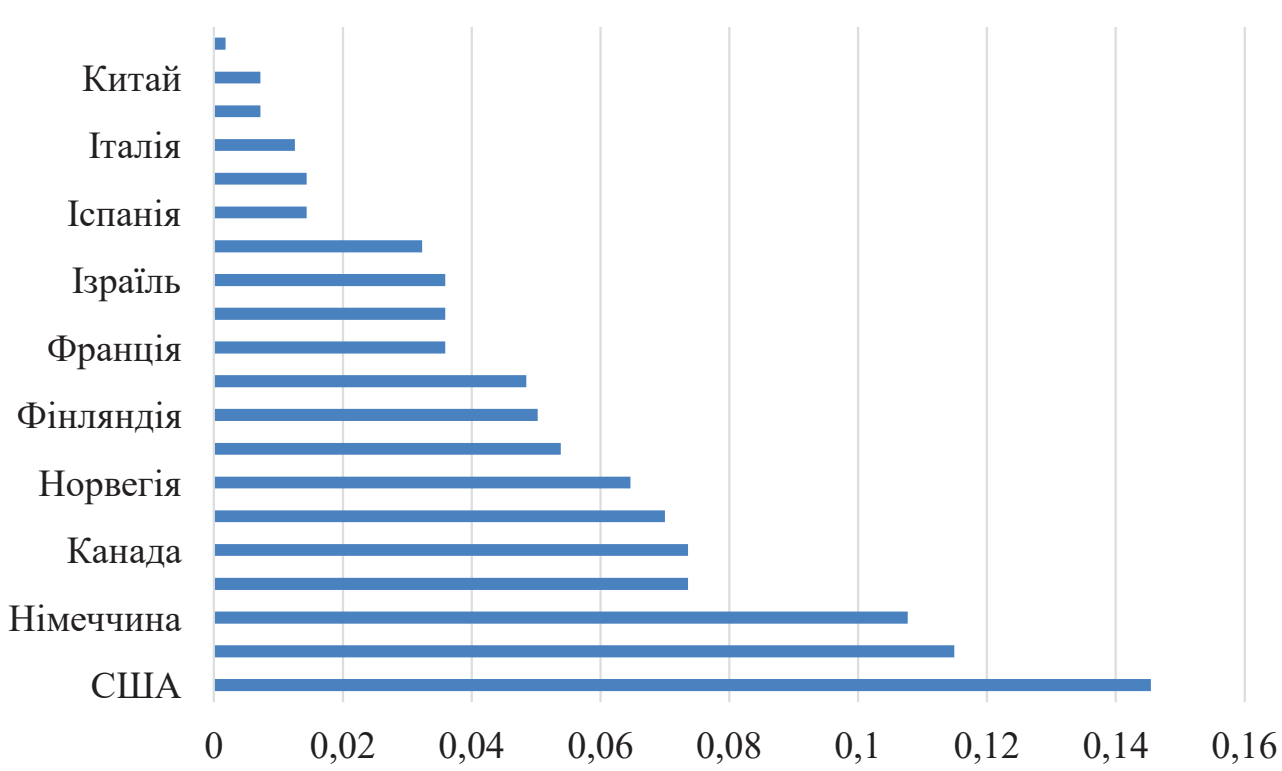

\section{Рисунок 5 - Основні цільові ринки експорту IT-послуг серед українських компаній} Джерело: [4]

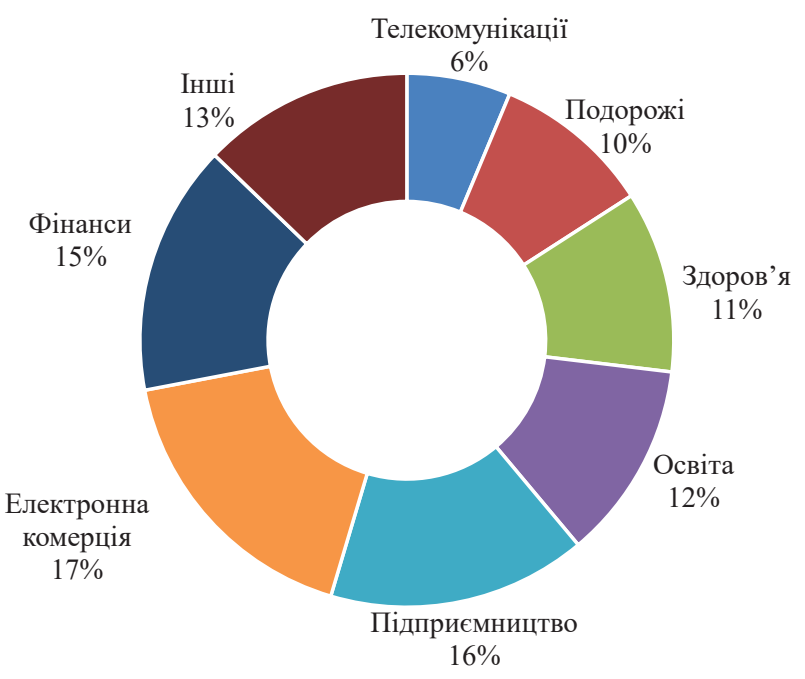

Рисунок 6 - Популярність ділових доменів серед компаній

Джерело: [4]

рішення для носіїв. Крім того, значна кількість українських компаній, що займаються мобільним розвитком, володіє досвідом у сфері IoT, AR/VR i навіть Blockchain.

Розвиток ігор - це ще одна процвітаюча частина українського IT-сектору. Згідно 3 даними Newzoo [7] на його ринку вартістю 195 мільйонів доларів Україна посідає третє місце серед країн Східної Європи і 42 місце у світовому рейтингу.

Цей сектор швидко розвивається, чому допомагають високий попит та цікаві проєкти, а кількість професійних розробників ігор в Україні також демонструє стійке зростання. Багато навчально-

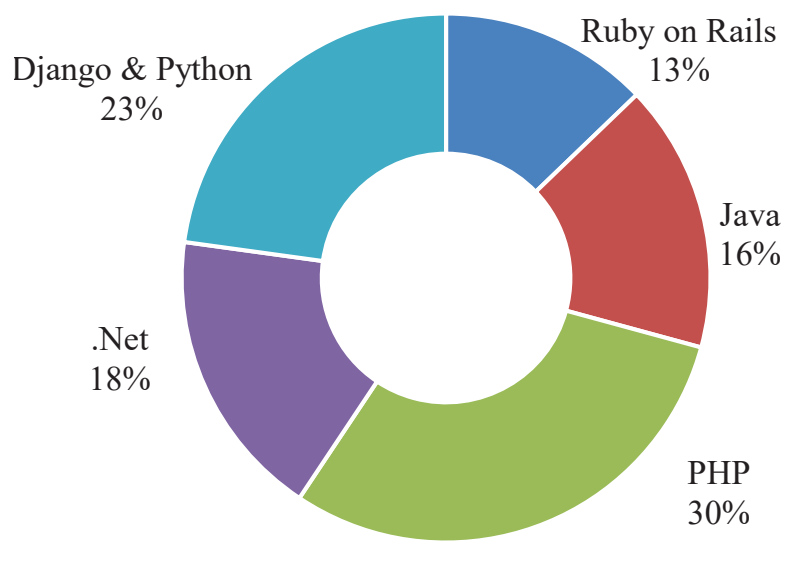

Рисунок 7 - Найпопулярніші WEB-технології серед компаній - розробників ПЗ

Джерело: [4]

тренувальних курсів 3 дизайну ігор на Unity3D відкриваються в країні для задоволення цього попиту.

Нині існує близько 100 компаній, які спеціалізуються як на мобільних/соціальних іграх, так і на відеоіграх, включаючи деякі всесвітньо відомі продуктові компанії. Деякими з найпопулярніших українських відеоігор $є$ S.T.A.L.K.E.R. i METRO 2033.

Останнім часом українська промисловість 3 розвитку ігор помітно зросла під постійним припливом інвестицій. Багато компаній $з$ розроблення програмного забезпечення в Україні 
проводять спеціалізовані тренінги, присвячені розробленню ігор.

Нижче наведені найбільш популярні моделі співробітництва, що використовуються компаніями в Україні.

1) Проєктний аутсорсинг. Згідно 3 цієї моделлю провайдер буде обробляти всі аспекти проєкту розроблення програмного забезпечення 3 нуля. Аутсорсингові компанії зазвичай пропонують кінцеві послуги, включаючи управління проєктами. Це означає, що для керування процесом клієнту не потрібні технічні знання. Відповідно, всі аспекти процесу розроблення обробляються продавцем 3 мінімальним залученням клієнта. Проте в типовій компанії, яка пропонує аутсорсинг проєктів, розробники працюють одночасно на декількох проєктах, що приводить до зниження темпів залучення розробників та більш низької відповідальності за проєкт.

2) Виділена команда. Спеціальна команда дає змогу клієнту краще контролювати процес розроблення програмного забезпечення та приводить до більш високої взаємодії з командою, головним чином тому, що інженери програмного забезпечення можуть зосередити увагу лише на одному проєкті. Водночас ця модель, як і раніше, не дає клієнту можливості вибрати власних розробників програмного забезпечення (зазвичай ви можете вибрати лише з обмеженої кількості кандидатів, наданих продавцем). Крім того, в цьому разі управління проєктами, як правило, виконується продавцем.

3) Розширена команди. Розширена команда $\epsilon$ вдосконаленою версією виділеної команди розробників. У цьому разі команда збирається, щоби конкретно відповідати потребам проєкту (співбесіду з розробниками проводить замовник, він же приймає рішення про найм самостійно). Крім того, замовник зберігає повний контроль над процесом розроблення. Завдяки прямому спілкуванню та мінімальним стороннім залученням у процес розробники стовідсотково залучені в проєкт і показують вищу продуктивність. Крім того, цей підхід спирається на модель «Вартість+», яка складається із заробітної плати розробника програмного забезпечення та фіксованої щомісячної плату за обслуговування.

Висновки. Отже, як ми бачимо 3 наведеної вище інформації, можна впевнено сказати, що український IT-ринок розвивається швидкими темпами. На ринку представлено більшість основних напрямів світового IT-сектору, що дає стабільний грунт, привабливий для вітчизняних та закордонних інвесторів. Можна впевнено передбачити, що IT здійснить значний внесок у розвиток української економіки.

\section{Список використаних джерел:}

1. Винничук Р., Склярук Т. Особливості розвитку IT-ринку в Україні: стан та тенденції // Національний університет «Львівська політехніка». 2015. URL: http://ena.lp.edu.ua (дата звернення: 25.01.2020).

2. Export-oriented segment of Ukraine's IT. URL: https://eba.com.ua/static/exportit_industryfinal_29092016.pdf (дата звернення: 26.01.2020).

3. Infoshare - the biggest tech conference in CEE. URL: https://infoshare.pl/news/one,66,246,1,central-eastern-europedeveloper-landscape-2017-a-report-by-stack-overflow.html (дата звернення: 26.01.2020).

4. DOU: Спільнота програмістів України. URL: http://dou.ua (дата звернення: 26.01.2020).

5. Hi-Tech Ukraine from A to Z. Software development \& IT services: The rise of a tech nation. Pre-release version. December. 2015. URL: http://www.uadn.net/files/ua_hightech.pdf (дата звернення: 24.01.2020).

6. Ukrainian HI-TECH Initiative. URL: http://hi-tech.org.ua/report-ukraine-powerhouse (дата звернення: 27.01.2020).

7. Newzoo / Games \& Esports Analytics and Market Research. URL: https://newzoo.com (дата звернення: 24.01.2020).

\section{References:}

1. Vinnichyc R., Sklaryk T. (2015).“Osobluvosti rozvitky IT-runky v Ukraine: stan ta tendencii”, Lviv Polytechnic National University, Lviv, Ukraine, available at: http://ena.lp.edu.ua (accessed: 25 January 2020).

2. The site of the Export-oriented segment of Ukraine's IT (2016), available at: https://eba.com.ua/static/export_it industryfinal (accessed: 26 January 2020).

3. Infoshare - the biggest tech conference in CEE (2017), available at: https://infoshare.pl/news/one,66,246,1,centraleastern-europe-developer-landscape (accessed: 26 January 2020).

4. DOU: Spil'nota prohramistiv Ukrayiny (2019), available at: http://dou.ua (accessed: 26 January 2020).

5. Hi-Tech Ukraine from A to Z. Software development \& IT services: The rise of a tech nation. Pre-release version (2018), available at: http://www.uadn.net/files/ua_hightech.pdf (accessed: 24 January 2020).

6. Ukrainian HI-TECH Initiative (2019), available at: http://hi-tech.org.ua/report-ukraine-powerhouse (accessed: 27 January 2020).

7. Newzoo / Games \& Esports Analytics and Market Research (2019), available at: https://newzoo.com (accessed: 24 January 2020). 
Roshchina Nadiia, Bordanova Liudmila

National Technical University of Ukraine "Igor Sikorsky Kyiv Politechnic Institute"

\section{A RETROSPECTIVE ANALYSIS OF THE INFORMATION TECHNOLOGY MARKET OF UKRAINE}

In the modern world, the development of the information and technology market is gaining momentum. The IT sphere is closely and dynamically integrated in all sectors of the world economy, directly affecting the overall growth of economic and social indicators of enterprises and organizations. Understanding the importance of information technology for the formation of sustainable competitive positions of organizations, development of all activities, improving the quality of goods and services, etc., leads to a steady demand for these technologies. In this way, there is a mutual influence of the IT sphere and other economic sectors in the external environment and on a transnational scale. For Ukraine, the IT sphere is of particular importance because, against the background of the general economic and political crisis, it is able to smooth these phenomena through rapid development, as well as to ensure the functioning of many related industries. A relatively young industry for our country (practically equal to an independent Ukraine), in addition to the immediate economic effect, today it has become an important element of stateof-the-art image: more than 100 representatives of the most successful companies Fortune 500 is a loyal customer of the domestic IT business, a leading international Global Sourcing Association honors Ukraine as the Best CountryMember for IT Services in the UK, a reputable American business magazine Inc. includes Ukrainian companies in the most dynamic list. All this is a truly significant result that has been achieved through years of hard work. But what will the Ukrainian information technology industry face if we are take a look at up-to-date official government data and sensitive business information from market players? What is the real share of IT business in Ukrainian exports and how, directly and indirectly, does the industry affect the country's economy?

Key words: information technology market, IT sphere, analysis, dynamics.

JEL classification: L86. 